\title{
UNIVERSITYOF
}

FORWARD

THINKING

WESTMINSTER用

WestminsterResearch

http://www.westminster.ac.uk/westminsterresearch

Fashion events and e-WOM

Ruiz-Alba, J., Morales, J., Ayestarán, R. and López Tenorio, P.

This article is @ Cognizant Communication Corporation and should not be further copied/distributed or hosted elsewhere without the express permission of Cognizant Communication Corporation.

This article was originally published in Event Management, DOI:10.3727/152599521X16192004803511 on 7 July 2021 and is available at:

https://doi.org/10.3727/152599521X16192004803511

The WestminsterResearch online digital archive at the University of Westminster aims to make the research output of the University available to a wider audience. Copyright and Moral Rights remain with the authors and/or copyright owners. 


\title{
Fashion events and e-WOM
}

[Accepted for publication (12/02/2021) in Event Management]

(Authors' version)

(Published Online: 07 Jul 2021)

Digital Object Identifier (DOI)

https://doi.org/10.3727/152599521X16192004803511

José L. Ruiz-Alba. University of Westminster, (London, UK).

Javier Morales Mediano. Universidad Pontificia Comillas, ICADE Business School, (Madrid, Spain).

Raquel Ayestarán Crespo. Universidad Francisco de Vitoria, (Madrid, Spain).

Pablo López Tenorio. University Autónoma de Madrid, (Madrid, Spain).

\begin{abstract}
The aim of this paper is to gain a deeper understanding of fashion events marketing from a sponsor's perspective and its influence on customers and society. We firstly seek to investigate what are the main marketing objectives of brands when they decide to sponsor fashion events; secondly, what are the main factors to enhance customer engagement with sponsoring brands; and finally, what are the most effective pathways to generate e-WOM in this context of fashion events. In order to answer these research questions, we conducted four studies: two Online Focus Groups, in-depth interviews and a fuzzy set Qualitative Comparative Analysis (fsQCA). Main findings show that the chief objectives of brands in sponsoring fashion events are: a) customer engagement with the sponsoring firm and, in particular, e-WOM, b) brand presence and c) brand positioning with fashion industry values. The conditions that enhance customer engagement are a) enjoyment, b) fashion values, c) sustainability and d) product knowledge. Fashion values are found to be a necessary condition to generate e-WOM. There are two conditions sufficient to produce e-WOM: a) the lack of enjoyment and fashion values or b) fashion values and sustainability.
\end{abstract}


Keywords: fashion event marketing; social media; sponsors; e-WOM; customer engagement; fsQCA. 


\section{Fashion Events And E-WOM}

\section{Introduction}

Fashion events have a relevant economic impact on different sectors, but also a huge influence on individuals and in society. Most fashion events serve as a platform or showcase of the fashion industry in new markets. The role of fashion events is crucial in a context in which the whole fashion industry is suffering a decline in most regions of the world and in most value segments, except in the two extremes: luxury and discount (McKinsey, 2020).

One of the main traits of the fashion industry is the regular organisation of multibrand events such as fashion weeks (Geissinger \& Laurell, 2020), which are becoming more transparent and open due to the impact of social media (Mohr, 2013).

Each fashion event has many stakeholders involved: organisers, brand designers, celebrity endorsers, general public, public attending the event and public digitally attending the event, amongst others. This study will focus on a specific stakeholder: the sponsors of fashion events. This is due to the importance of sponsors as, without them, most fashion events could not take place and the second reason is because there is a lack of research about the motivations of sponsors when they decide to sponsor fashion events and also about the assessment of how they are achieving their marketing objectives. Geissinger and Laurell (2020) recently found that fashion weeks created increased engagement with fashion in general and focused engagement on participating brands in particular, but there is still a relevant gap regarding the engagement with the sponsoring brands of fashion events.

The role of marketing is crucial from a sponsor's perspective and, as such, we will investigate how to gain customer attention and engagement. This becomes more important in a context where there is a shift towards experience over exchange and trade shows, where showrooms are becoming less important for the fashion industry (McKinsey, 2020) and there is a trend to move towards an omnichannel approach. 
The most important fashion events in the world take place in New York, London, Paris, Berlin, Milan, Madrid, Los Angeles, Shanghai, etc. However, these events are only made possible thanks to the involvement of sponsoring brands. A good example of a successful engagement of fashion event organisers with sponsoring brands is Madrid. Mercedes Fashion Week in Madrid (MFWM) can help us to illustrate the crucial role of sponsoring brands in fashion events. In the last edition of MFWM, 18 brands sponsored the event: Mercedes-Benz, L'Oréal Paris and Inditex, as principal sponsors, and Samsung, Dyson and Iberia amongst others. The involvement of sponsoring brands made it possible for around 100 designers and fashion brands to participate; each designer spends between $€ 40,000$ and $€ 270,000$ on their "catwalks" (ACME, 2020). The last edition of MFWM -January 2020- had more than 1,000 accredited press professionals, more than 55,000 visitors to the premises, 220,000 users of the organisation' website and more than 50,000 users and 350,000 social media followers (IFEMA, 2020).

Although technically they are not considered in most cases as direct sponsors, it is important to note that some regional and local governments also offer grants to young designers to support new talent and to help them to get international exposure thanks to the visibility offered by a fashion event.

Due to COVID-19, the digital presence of this fashion event will be enhanced with a hybrid format through a new digital platform and this opens up new opportunities for sponsors to enhance their digital presence and customer engagement. Barcelona Fashion Week has a relevant impact in the sector and is shifting quickly to digital environments. South America is gaining interest for the fashion industry and fashion events are gaining momentum. For instance, Bogotá Fashion Week is a very important fashion event in Colombia, as the fashion industry generates $17 \%$ of the manufacturing sector. Every year, 
this fashion event gathers around 150 fashion brands and has more than 20 sponsors (Bogotá Fashion Week, 2020).

It is important to understand the new and changing role of fashion events. In fact, during many years sponsoring firms have been mainly focused on two aspects: their brand reputation and the impact of their presence in the event on the image of the company (Gwinner, 1997). However, this has changed as firms are interested also in facilitating customer engagement, but this received limited attention from researchers even though fashion events have a high influence in gaining customer engagement with the sponsoring brands of the events. Major trade shows are rethinking their purpose and focusing more on the attendee experience (McKinsey, 2020). For instance, Pure London, a fashion show that attracts 17,000 visitors, has decided to give more prominence to sustainability initiatives.

Mair and Witford (2013) conducted a thorough study about event research and, although they contributed with very interesting findings, branding and sponsoring of events was not present in the research agenda about events. There is a relevant gap in the discipline that requires attention from researchers. Consumers' expectations are continually changing and it is worth investigating how events are shaping those expectations and their attitude towards brands and behaviour in social media.

To the best of our knowledge, no previous studies have openly sought new outcomes of sponsoring activities other than sports. In particular, we found of high interest the work of Brambilla et al. (2017) who discovered the importance of social media in the propagation of fashion events through different audiences. Their study opened a promising research avenue, which is the study of consumers' outcomes due to fashion events sponsoring (other than sports) in relation to the use of social media. Two key outcomes from consumers expressed through social media are e-WOM and customer engagement (Choi et al., 2017). In that sense, sponsoring brands in their efforts to attract new customers try to enhance customer 
engagement (Wang \& Fesenmaier, 2004) that has a behavioural approach (Verhoef et al., 2010) further than just purchasing.

This investigation is guided by three research questions. Firstly, regarding the role of sponsoring brands of fashion events, we propose RQ1, a): What are the main marketing goals of sponsors of fashion events? And RQ1, b): When a brand decides to sponsor a fashion event, what are the main fashion values that the sponsor seeks to be associated with (positioning)? This research question was addressed with the participation of six experts in an Online Focus Group (OFG1) using Padlet.

In relation to customer engagement and e-WOM, we propose RQ2, a): What are the main variables to enhance customer engagement through sponsorship of fashion events? And RQ2, b): What are the main antecedents for e-WOM through sponsorship of fashion events? This research question was addressed with the participation of seven experts in a second Online Focus Group (OFG2) using Google Groups.

Once the main antecedents of e-WOM were identified, we wanted to deal with the causal complexity of the conditions and configurations of conditions; therefore, we proposed RQ3: What are the pathways of conditions that lead to e-WOM? In order to answer this question, we conducted a fuzzy set Qualitative Comparative Analysis (fsQCA). This research question was investigated using in-depth interviews with 22 participants followed by a calibration of responses and the subsequent fuzzy set Qualitative Comparative Analysis using fsQCA software (Ragin, 2000).

\section{Literature Review}

\section{Fashion Events Marketing}

The study of events has been of research interest for a few decades (Cudny \& Rouba, 2012). There are numerous event classifications in the literature (Getz, 2005; Jago \& Shaw, 
1998). According to Cudny and Rouba (2012), fashion events are periodic hallmark events (Getz, 2005) in the group of trade events (Getz, 2008). These are a particular type of event that originated at the end of the XIX century and for an elite of society of the time (Rocamora, 2017). However, nowadays, fashion events are no longer for an industry-related audience, but for the general public. They have transformed into authentic public entertainment shows that call the attention of both types of audience (Rocamora, 2017).

On the one hand, fashion events are a type of touristic attraction claimed by either top tier cities like New York or London or smaller cities like Melbourne or Belgrade (Demirović \& Pivac, 2013; Webster, 2104). Fashion events are, in many cases, not only an initiative of the industry, but also of local governments to drive the place branding of the city hosting the event (Sachuk \& Corrêa, 2007).

On the other hand, precisely due to the attention that fashion events are able to attract, they have become an essential marketing tool for fashion and luxury companies (Shand, 2014). This includes both types of companies: purely clothing companies that use fashion events to present their new collections and try to attract more customers (Mohr, 2013), and other related companies that, by means of sponsoring fashion events, try to cover many marketing activities, such as brand building, launching of new products or improvement of their social media presence (Chaturvedi, 2011; Mohr, 2013).

\section{Sponsorship of events}

Sponsorship of events has been an essential communication tool for companies in the recent history of marketing (Grohs, 2001; Javalgi at al. 1994). Initially, the interest of companies engaged in sponsoring activities was solely concerned with influencing the image of their brands by effectively appearing as the sponsor of the event (Gwinner, 1997). This influence occurs because of the connection made by the audience between the sponsor and 
the brand. According to Bruhn and Holzer (2015), this connection is known by several terms, such as fit, link, congruence, or similarity. Gwinner (1997) stated that the image transfer can be functional based, when the product is used during the event, or image based. Additionally, Abreu and Arcodia (2013) worked on differentiating the level of image transfer between those attending the event and those watching the event on television.

Several authors have worked on proving the importance of this fit (e.g. Bruhn \& Holzer, 2015); however, limited studies have delved into the impact that the brand-event link, in particular, and the sponsoring activity, in general, can generate in the consumer attitude and behaviour. Lee et al. (1998) attempted to identify the potential attitudes of consumers; however, amongst the three proposed constructs, only buying intention was behavioural in nature. Again, Ko, et al. (2017) further developed the model of the perceived connection. They described four dimensions of the connection sponsor-event: prominence, ubiquity, sincerity, and congruence, but mainly focused on the overall attitude of consumers towards sponsors. An exception to this lack of concretion is the study of Tsiotsou and Alexandris (2009) who researched and proved the positive impact of sponsoring activities on purchasing and recommending intentions. Nevertheless, their investigation was limited to the field of sporting events and fans, not the general public.

\section{E-WOM and customer engagement}

Electronic word of mouth (e-WOM) comes from the concept of word of mouth (WOM), originally defined as "informal communications directed at other consumers about the ownership, usage, or characteristics of particular good and services or their sellers" (Westbrook, 1987, p. 261). In particular, e-WOM has been defined as "any positive or negative statement made by potential, actual or former customers about a product or company, which is made available to a multitude of people and institutions via Internet" 
(Hennig-Thurau et al. 2004, p.39). Recently, Vermeer et al. (2019), based on a sentiments perspective, classified three main types of e-WOM: positive, negative and neutral, but it can also be classified based on content analysis: are customers posting about their experience, about product attributes or other aspects related to the service or brand. According to Erkan and Elwalda (2018), the different characteristics of eWOM messages influence the consumer intention to engage with a brand.

Additionally, So et al. (2016) proved that the particular assessment of a consumption experience with a brand largely impacts the link between this experience and brand loyalty. However, it is not clear as regard the evaluation of service experience for the case of interaction with a sponsoring brand for which consumption has not yet happened, but there is evidence of customer engagement. These customer engagement behaviours should help sponsoring brands to attract future customers, as happens in other contexts (Wang \& Fesenmaier, 2004). The conceptualisation of customer engagement has a clear behavioural component (Verhoef et al., 2010) that includes different elements that go beyond a purchase or consumption.

A very important element in customer engagement is related to recommendations, which incorporates not only the behavioural dimension, but also the cognitive and affective ones. In that sense, enthusiasm signifies a strong level of excitement regarding a type of engagement that can activate recommendation intentions and action. It has been shown that social relationships play an important role in e-WOM (Hsu \& Tran, 2013). A positive customer experience can enhance customer engagement. Moreover, customer experience is conceptualised as a construct with several dimensions: cognitive, affective, physical but also social as experience can be co-created with other people in social contexts (Bustamante \& Rubio, 2017). This has clear implications for attendees to fashion events who, based on their experience, can become engaged in e-WOM behaviours. 
Although there is a lack of use of theories to the understanding of the role of customer engagement and e-WOM in the sponsorships of event, however the congruity theory (Meyers-Levy \& Tybout, 1989) could be applicable as congruity has also been used in advertising and consumer behavior when investigating the role of third parties are linked to an object, such as a brand or company (Solomon, 1996). In relation to the relationships of the other variables under investigation in this research, the social exchange theory can also be considered as a relationship is dependent on the strength of its social interactions. The social exchanges which take place throughout the relationship define the value (Blau, 1964).

\section{Methodology}

This research integrates four studies with a total of 35 different participants: Study 1 consisted of an Online Focus Group (OFG1) using Padlet (six participants); Study 2 consisted of a second Online Focus Group (OFG2) using Google Groups (seven participants); Study 3 was conducted using in-depth interviews (22 participants) and finally Study 4 was a fsQCA with 22 cases.

Participants had a broad knowledge of fashion events in different cities and countries, but they were mainly experts in the sector of Spain and Hispanic America and also attendees to fashion events. Purposive sampling was used, and data saturation was considered (Charmaz, 2006; Glaser \& Strauss, 1967).

The collection and analysis of data from different studies was carefully designed and implemented with the lens of grounded theory using data from diverse sources (Glasser \& Strauss, 1967). The effort to integrate these four independent studies was guided with the aim to provide more consistency to the overall investigation (Yin, 2015). 


\section{Design of the studies and data collection}

The selection of participants in the different studies of this investigation was conducted free of any bias or convenience. The three criteria chosen were: 1) professional experience of more than 5 years in the sector; 2) no personal or professional relationship with any of the authors of this investigation; 3 ) fit with the specific objectives of each study according with what is detailed in Appendix A.

\section{Studies 1 and 2}

Studies 1 and 2 consisted of Online Focus Group (OFG1 and OFG2). The OFG1 was conducted using Padlet with six participants (marketing experts, practitioners, academic from fashion schools and researchers).

Study 1 was done in an asynchronous way. The objective of OFG1 was to answer RQ1a), what are the main marketing goals of sponsors of fashion events? and RQ1b), when a brand decides to sponsor a fashion event, what are the main fashion values that the sponsor seeks to be associated with (positioning)? The Padlet was configured in posting these two research questions and the participants were given 48 hours to make their comments and interact with other participants. They were asked to join anonymously with fictional names and to participate at least in two different moments to allow discussion and to make comments on other participants' posts. One member of our research team moderated the OFG1 and contributed to assure that the main themes were covered. When an aspect needed clarification, the moderator highlighted it and encouraged participants to answer with more depth on these discussion areas. The final output of data was a PDF document downloaded from Padlet with the comments from participants.

\section{Study 3}


For Study 3, we designed a protocol to accompany the questions of the interview. This protocol was comprised of an introduction to the research and the relevant aspects of our inquiry (Arsel, 2017). Participants were selected according to theoretical sampling (Corbin $\&$ Strauss, 1990) as we searched for contributions from practitioners from different companies involved in event sponsoring. The interviews were semi-structured, allowing participants to make questions, to bring new topics to the conversation and to reflect on their thoughts (Kvale, 1983).

We interviewed a total of 22 executives of top brands that had involved in sponsoring fashion events during at least the last three years. The interviews were transcribed and exported to NVivo 12. Following the recommendation from Corbin and Strauss (1990), two members of the research team applied open, axial and selective coding processes to the data. The coded data were then used to extract the results presented in the corresponding section. All transcripts were read several times by all co-auhtors and themes developed, In addition, the codes and themes were applied consistently throughout the different documents. In this study, we did the calibration by adapting the technique developed by Basurto and Speer (2012). This will be discussed later. It is important to note that the sample of the 22 experts is the same for studies 3 and 4 .

\section{Study 4}

Fuzzy-set qualitative comparative analysis (fsQCA) (Ragin, 2000) is an analytical method based on set theory and Boolean algebra to identify necessary or sufficient conditions, either by themselves or in combination with one another, causally linked to an outcome. It is important to note that fsQCA differs from regression analysis and conventional statistical techniques as it allows researchers to go beyond the net effect analysis to acquire 
more insights about the configurational complexities of the relationships between antecedent conditions and outcome (Woodside, 2013).

\section{Results and discussion}

\section{Results from Study 1 and discussion}

As explained before, the main objective of Study 1 was to answer the RQ1a and RQ1b).

The OFG1 has shown that the main marketing objectives of sponsors of fashion events were: 1) to enhance customer engagement with the sponsoring brand and, in particular, e-WOM, 2) brand presence and c) brand positioning with fashion industry values. There was a clear consensus amongst participants that the main marketing objective of sponsors of fashion events was to foster and increase customer engagement with sponsoring brands. A comment from one participant well-illustrates this idea: “When I proposed my CEO, in my role of marketing director, to sponsor a fashion event, the first question that she made to me was: What will be the main benefit of sponsoring a fashion event? I responded to her that I had several objectives, but when she heard that I wanted to increase customer engagement, then she interrupted me and said that she didn't want to hear other objectives as this was relevant enough. So, she gave green light straight away to my proposal."

More than half of the participants highlighted the importance of the use of newsletters to increase customer engagement. One of them expressed: "We are aware that the official website of the fashion event organiser has a newsletter. We work closely with them to make sure that there is information about our brand as sponsors. And, we have created our own newsletter with news and perspectives about the fashion event and we work hard with our community managers to get more subscribers to our newsletter”. 
Although the use of a newsletter was important, all of them agreed that the best way to measure customer engagement with the brand was e-WOM. This following comment reflects a general agreement: "For us, electronic word of mouth is by far the best indicator of a high-quality level of customer engagement with our brand. We measure e-WOM, not only every day, but every minute.”

This OFG1 also addressed the RQ1b) about the main fashion values that sponsors seek to be associated with (positioning) when they decided to sponsor a fashion event. All the interventions were coded and analysed by researchers of this study and we found that the main values found were: dynamism, trendiness, flexibility, creativity and design.

One of the participants expressed: "We have been sponsoring fashions events for the last five years. Every year we monitor our brand and how it is perceived by our customers and followers. Since we started sponsoring the fashion event, be have evidence that the positioning of our brand has been shifting from a traditional, let's say 'classic' status towards a more dynamic, flexibly and trendy brand. This repositioning is clearly helping us to connect better with younger generations of customers what is one of our main strategic marketing priorities."

\section{Results from Study 2 and discussion}

As explained before the main objective of Study 2 was to answer RQ2, a) What are the dimensions and variables to enhance customer engagement through sponsorship of fashion events?; RQ2, b) What are the main antecedents for e-WOM through sponsorship of fashion events?

The OFG2 was conducted using Google Groups. The main finding was the identification of the four causal conditions to generate e-WOM: a) enjoyment; b) fashion values; c) sustainability and d) product knowledge. The themes emerged using inductive 
approach and not restricted to pre-determined codes (Creswell, 2009). This provides interpretation of the data free of bias.

Most participants agreed that the main causal condition that generates e-WOM is enjoyment. In that sense, one manifested: “during the fashion event we monitor our social media channels continually and we carry content analysis to better understand what do our followers post related to their interaction with the fashion event. Clearly the main theme is related to having fun, enjoying the event. The hedonic dimension of their experience." One participant expressed: "in the past, one of our main priorities during fashion events was $B 2 B$ relationships and public relations outcomes. But now our main priority is to provide to final consumer attendees the best experience that must be memorable. This also applies to those engaged with us through social media or other digital channels."

Fashion values were the second causal condition that generates e-WOM. As we identified in Study 1, the main values associated to fashion were: dynamism, trendiness, flexibility, creativity and design. In Study 2, we found that trendiness and creativity were the values that had a higher impact on e-WOM. In this sense one of the experts discussed: "When we analyse the content of the social media messages of followers, we find that trendiness and creativity are mentioned very frequently. This is what they mainly want to share in social media. Definitely we expect that the presence of our brand as sponsors of the event, to some extent will be also associated with those values as they are perceived by followers. In fact, we are thrilled to see that our brand can be perceived as trendy and creative as the fashion industry itself is being perceived."

Sustainability initiatives were also highlighted as one of the main values that had presence in the posts and comments from participants in fashion events. One participant expressed: "It is automatic: any time there is a bit of information about something related to sustainability (positively or negatively) it is impressive to see how the number of tweets and 
likes increases exponentially. It is a clear indicator of the interest in this topic, particularly in younger generations.”

\section{Results from Study 3 and discussion}

The in depth-interviews helped to gain a deeper understanding of the previous findings from Studies 1 and 2. One of the findings was that we suggest removing the fourth causal condition, 'knowledge of the product'. Even though it was found as a possible reason why participants in fashion events develop e-WOM, most experts interviewed in Study 3 agreed that, based on their experience, information about the product/service of the sponsoring firm was not mainly shared on social media by participants in fashion events sponsored by them. In that sense, one participant stated: "It is obvious that participants in fashion events will have a better knowledge of our products and services as sponsoring brands. But this doesn't mean that they will talk about products or services when they are engaged with fashion events. Our experience and the data that we have clearly indicate that their 'minds' are more focused on other aspects and they share more about their experience in the fashion event." Another participant said: "they don't mention our products. They mainly talk in social media about how they had fun in the fashion events, their interaction with our sponsoring brands in the stands that we have there and surprisingly they mention heavily sustainability concerns."

As we indicated in the methodology section regarding Study 3, for the calibration from qualitative data to fuzzy-set values we have adapted the technique developed by Basurto andSpeer (2012). These authors pointed out the lack of methods and technique to do a calibration from qualitative data. As no procedure was available, they developed a 6- step technique. In our case, it was not necessary to follow strictly the six steps that they proposed as we had our previous Studies 1 and 2, where we developed and defined the conditions and 
the outcome. All the measures were assigned with specific definitions. This helped to identify variations, possible biases and contradictions. This exercise was useful to confirm that we did not need to remove any of the measures for each condition or outcome.

Working with wider scales allows to measure with more precision the opinion of the interviewees, capturing greater variability in the response, which results in a higher quality of the data obtained. After that, we followed the method of calibration proposed by Ragin (2008) to convert the conventional variables (measured using a 7anchor points definitions) into fuzzy variables (continuous variables with values ranging from 0.0 to 1.0 to indicate the degree of membership of cases in the target set) using three qualitative anchors: 1.0 for full membership, 0.5 for the crossover point and 0 for full non-membership. We transformed the original variables using the principle of calibration as recommended by Wu et al. (2014). Therefore, we set the three qualitative anchors as follow: 7 as the threshold for full membership, 5 as the crossover point, and the full non-membership threshold was fixed at the rating of 3 .

As we have indicated, one of the results was the purification of conditions. In fact, there was a consensus that the condition COND4, 'Product Knowledge', should be removed from the subsequent fsQCA, as previously explained.

Regarding the interview guidelines, we created a section for each condition (enjoyment, fashion values and sustainability) and outcome (e-WOM). In total, we had four sections. We provided specific questions of each measure of each condition. Each measure consisted of a list of seven definitions. Once this process was completed, we proceed to match the qualitative classification to fuzzy-set values, as previously indicated.

\section{Results from Study 4 and discussion}


With the data resulting from the calibration in Study 3 we conducted, in Study 4, an fsQCA analysis. The main finding was the configuration of causal conditions and the identification of pathways that led to the outcome.

The first stage of data analysis includes the Spearman's correlation coefficients among the study's variables (Table 1). As shown in the table, none of the estimated correlation coefficients between e-WOM and the three causal conditions has an absolute value higher than 0.80 . This finding confirms that the relationships between e-WOM and every single causal condition are asymmetric, and, thus, alternative combinations of causal conditions can generate the same outcome (Woodside, 2014).

\section{INSERT HERE TABLE 1}

Because the relationship between e-WOM and causal conditions is asymmetric, we confirm that is more suitable in this case to use fsQCA than conventional regression analysis. We use fsQCA to identify conditions or combinations of conditions that are necessary or sufficient for the outcome (e-WOM). First, we perform the analysis of necessity the results of which are shown in Table 2 and indicate that there is a condition that stands out above the rest observing its consistency value: fashion values (0.801840). When a condition shows a consistency value that is close to 0.9 , it can be considered a necessary condition to the outcome (Schneider et al., 2010).

\section{INSERT HERE TABLE 2}

Regarding the analysis of sufficient conditions, and following the recommendation of Ragin and Sonnett (2005), we show the complex solution in Table 3. This solution yields that 
there is no single way to reach e-WOM. Particularly, there are two different pathways leading to e-WOM with high overall coverage of 0.74 and a consistency of 0.82 .

\section{INSERT HERE TABLE 3}

Formulae of pathways

$$
(\sim \mathrm{Enj} * \mathrm{Fv})+(\mathrm{Fv} * \text { Sust }) \square \mathrm{e}-\mathrm{WOM}
$$

Pathway 1 (raw coverage $=0.62$, unique coverage $=0.21$, consistency $=0.83)$ combines the absence of enjoyment ( $\sim$ cs_X1_Enjoy) with the presence of fashion values (cs_X2_Fashion). In this configuration, fashion values seem to play a significant role to lead e-WOM for the absence of enjoyment.

Pathway 2 (raw coverage $=0.53$, unique coverage $=0.12$, consistency $=0.91)$ describes a combination of the presence of fashion values (cs_X2_Fashion) with sustainability (cs_X3_Sustainability).

We found that there are two sufficient configurations of conditions: the lack of enjoyment and fashion values or fashion values and sustainability. The final configuration was ( Enjoyment and Fashion values) or (Fashion values and Sustainability) $=$ e-WOM.

Although there are two sufficient configurations of conditions leading to e-WOM, pathway 1 has higher capacity to lead e-WOM (raw coverage $=0.62$ ) than pathway 2 (raw coverage $=0.53$. Furthermore, the fashion values condition is present in both pathways, confirming that it is a necessary condition to achieve e-WOM.

\section{Limitations and future research}


One of the limitations of this research is that we have collected data from experts of Spain and Hispanic America. Although we gathered information from participants with broad knowledge of fashion events in different countries, we would suggest conducting further studies including other regions of the world.

It would be relevant to investigate how the values associated to fashion influence eWOM, and, specifically, which values have a higher impact on e-WOM and what type of influence.

Based on the importance of sustainability in the context of fashion events, we suggest that more research is needed in sustainable fashion, encompassing a variety of elements such as organic, green, fair trade, sustainable, slow and eco, recycling clothing, boycotting a company and buying fair-trade clothing (Cervellon et al., 2010; Jägel et al., 2012).

The present study also opens the possibility of developing in more depth a conceptual framework based on the contributions of this research. Specifically, enjoyment, sustainability and fashion values can be considered as antecedents of e-WOM in the context of sponsoring brands of fashion events. With e-WOM being an essential part of customer engagement, this will also open interesting avenues to investigate the consequences of e-WOM.

\section{Conclusions and implications}

We found that the main goals of firms sponsoring fashion events are a) customer engagement with the sponsoring brand and in particular e-WOM, b) brand presence and c) brand positioning with fashion industry values. Another finding was related to the factors that enhance customer engagement. We identified four: a) enjoyment, b) fashion values, c) sustainability and d) product knowledge. Finally, we found that fashion values are a necessary condition to generate e-WOM. There are two sufficient conditions to produce eWOM: a) the lack in enjoyment and fashion values or b) fashion values and sustainability. 
The structure of the research design of this paper can be found in Appendix A.

One interesting contribution is related to the finding and discussion of the fact that brands which sponsor fashion events have experienced a change in their positioning. Gwinner (1997) explained that changing their brand image was one of the main goals for companies sponsoring events. Our research has proven that this shift comes from the way they were perceived from more traditional to trendier. This was highlighted by Chaturvedi (2011), who pointed out some specific features, such as fashionable, that can be associated with sponsoring brands. An important managerial implication of this conclusion is that changing the positioning of brands to more attractive features, like trendiness, could help companies who want to connect with younger generations of consumers, in particular generation $\mathrm{z}$.

Another key conclusion offered by this study is that brands who sponsor fashion events can also benefit from the association to other fashion values, such as dynamism, flexibility, creativity and design. This should be a clear track for companies willing to be perceived as a brand with high design. Managers, and practiotioners in general, should thoughtfully consider the option of getting involved in fashion events in order to improve their companies' positioning in that sense.

It is also interesting to see that one of the main reasons that drive the interaction of customers in social media is the identification of the sponsoring brand with values associated to fashion. Gwinner (1997) proposed how the brand image and values are created through the sponsoring of events, whereas Lee et al. (1997) confirmed that sponsoring events affect the consumer attitude toward behavioral intents, such as paying more attention to brand communications. Indeed, brand image of sponsoring companies positively impact the involvement of consumers in word-of-mouth activities (Tsiotsou \& Alexandris, 2009). On this regards, this research hereby confirm that fashion values are a necessary condition that is present in the two configurations of conditions (pathways) that lead to e-WOM. This brings a 
notable practical implication for practitioners; fashion values are key amongst the different ones that can be transferred from an event to the sponsoring company if the company seeks to stimulate e-WOM from their customers. In other words, if sponsoring firms of fashion events are planning to enhance e-WOM as part of their strategies, they should clearly highlight the fashion values, as this is necessary condition to generate e-WOM.

However, what apparently could be considered as a main drive for e-WOM, the enjoyment during the fashion event, in the causal analysis appears as a condition that is not necessary, but, moreover, that is not sufficient. In fact, in the first pathway, it appears as that it needs not to be present, but should happen along with fashion values. Therefore, the hedonic aspect of customer experience surprisingly is not the main driver to develop e-WOM. Hsu and Tran (2013) and Choi et al. (2017) pointed already at this direction when confirmed some social factores that cause eWOM. This implication can be taken into consideration by organisers of fashion events who could avoid the simplistic assumption that only the fact of having fun during a fashion event will make them active apostles in social media. This interesting conclusion could also benefit fashions events sponsors in order to better focus their communication strategies before, during and after the fashion events.

The other sufficient condition is the causal configuration of fashion values and sustainability. The concern of customers regarding sustainability has been proven to be important in this research as it drives customers involvement in e-WOM communications. Although sutainability concern is not something new in relation to fashion, in fact, the first anti-fur campaigns appeared in the 1980s, during the last years we can see a huge increase in sustainable fashion consumption (Lundblad \& Davies, 2016). However, brands do not always communicate well their commitment with sustainability; just as an example, a report in the context of fashion brands in Italy found that $37 \%$ found that it was hard to discern ecofriendly brands (Statista, 2020). 
Based on findings from our study, this necessary condition of fashion values is configured through two sufficient conditions: one is the lack of enjoyment and the presence of fashion values and the second one is the presence of fashion values and sustainability. This will help fashion event organisers and sponsors to fine tune their target audiences and strategies, adding more $\mathrm{B} 2 \mathrm{C}$ attractions or launch new services and experiences to improve relationships with their traditional B2B audience (McKinsey, 2020). 


\section{APPENDIX A}

\section{Research Design Structure}

\begin{tabular}{|c|c|c|c|}
\hline & & Method & Findings \\
\hline Aim & $\begin{array}{l}\text { Better understanding of marketing } \\
\text { fashion events, in particular: a) goals } \\
\text { of sponsors; b) what is most effective } \\
\text { for customer engagement; c) what } \\
\text { drives e-WOM }\end{array}$ & & \\
\hline RQ1 & $\begin{array}{l}\text {-a-What are the main marketing goals } \\
\text { of sponsors of fashion events? } \\
\text {-b- When a brand decides to sponsor } \\
\text { a fashion event, what are the main } \\
\text { fashion values that the sponsor seeks } \\
\text { to be associated with (positioning)? }\end{array}$ & $\begin{array}{l}\text { Marketing experts, } \\
\text { practitioners, academics from } \\
\text { fashion schools, researchers } \\
\text { (six participants) } \\
\text { Study 1. Online Focus } \\
\underline{\text { Group-1 }} \\
\underline{\text { (Padlet) }}\end{array}$ & $\begin{array}{l}\text { a) Customer engagement with the sponsoring } \\
\text { brand and, in particular, e-WOM; b) Brand } \\
\text { presence and c) Brand positioning with fashion } \\
\text { industry values: dynamism, trendiness, } \\
\text { flexibility, creativity and design. }\end{array}$ \\
\hline RQ2 & $\begin{array}{l}\text { What are the main conditions to } \\
\text { enhance customer engagement } \\
\text { through sponsorship of fashion } \\
\text { events? } \\
\text { What are the main antecedents for e- } \\
\text { WOM through sponsorship of fashion } \\
\text { events? }\end{array}$ & $\begin{array}{l}\text { Experts (seven participants) } \\
\text { Study 2. Online Focus } \\
\underline{\text { Group-2 }} \\
\underline{\text { (Google Groups) }}\end{array}$ & $\begin{array}{l}\text { Identification of four conditions } \\
\text { IND1 Enjoyment } \\
\text { IND2 Fashion Values } \\
\text { IND3 Sustainability } \\
\text { IND4 Product Knowledge }\end{array}$ \\
\hline RQ3 & $\begin{array}{l}\text { What are pathways of conditions that } \\
\text { lead to e-WOM? }\end{array}$ & 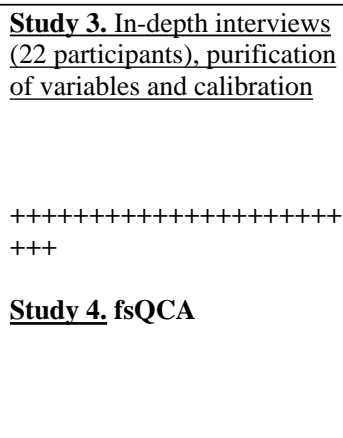 & 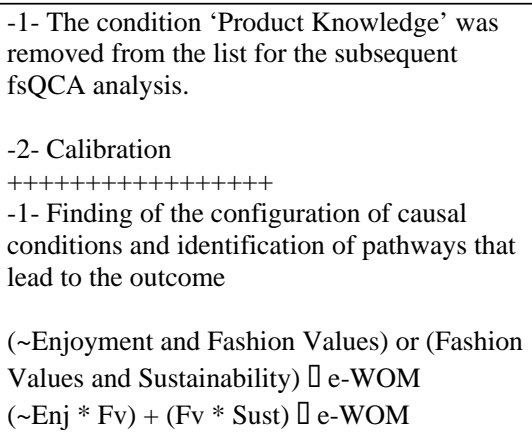 \\
\hline
\end{tabular}




\section{References}

Abreu Novais, M., \& Arcodia, C. (2013). Measuring the effects of event sponsorship: Theoretical frameworks and image transfer models. Journal of Travel \& Tourism Marketing, 30(4), 308-334. https://doi.org/10.1080/10548408.2013.784149

ACME (2020). Asociación de Creadores de Moda de España. Informe Madrid Capital de Moda. http://www.madridcapitaldemoda.com/wp-content/uploads/2020/04/Dossierde-Prensa-MCDM.pdf

Arsel, Z. (2017). Asking questions with reflexive focus: A tutorial on designing and conducting interviews. Journal of Consumer Research, 44(4), 939-948. https://doi.org/10.1093/jcr/ucx096

Basurto, X., \& Speer, J. (2012). Structuring the calibration of qualitative data as sets for qualitative comparative analysis (QCA). Field Methods, 24(2), 155-174. https://doi.org/10.1177/1525822X11433998

Blau, P. (1964), Exchange and Power in Social Life, Wiley, New York, NY.

Bogotá Fashion Week (2020). https://www.bogotafashionweek.com.co/

Brambilla, M., Ceri, S., Daniel, F., \& Donetti, G. (2017, April). Spatial analysis of social media response to live events: The case of the Milano fashion week. In Proceedings 
of the 26th International Conference on World Wide Web Companion, 1457-1462. https://doi.org/10.1145/3041021.3051698

Bruhn, M., \& Holzer, M. (2015). The role of the fit construct and sponsorship portfolio size for event sponsorship success. European Journal of Marketing, 49(5/6), 874-893. https://doi.org/10.1108/EJM-09-2012-0517

Bustamante, J. C. \& Rubio, N. (2017). Measuring customer experience in physical retail environments. Journal of Service Management, 28(5), 884-913. https://doi.org/10.1108/JOSM-06-2016-0142

Cervellon, M., Hjerth, H., \& Ricard, S. (2010, January). Green in fashion? An exploratory study of national differences in consumers concern for eco-fashion. In Proceedings of $9^{\text {th }}$ International Marketing Trends Conference. https://www.compromisorse.com/upload/estudios/000/114/GreenFashion.pdf

Chaturvedi, A. (2011). Sponsoring fashion events for right publicity: Sponsored fashion weeks have spawned a uniquely Indian brand ecosystem. Business Today. https://www.businesstoday.in/magazine/features/fashion-weeks-in-indiasponshorship/story/18674.html

Charmaz, K. (2006). Constructing grounded theory: A practical guide through qualitative analysis. Thousand Oaks, CA: Sage. 
Corbin, J., \& Strauss, A. (1990). Grounded theory research: procedures, canons, and evaluative criteria. Qualitative Sociology, 13(1), 3-21.

Creswell, J. W. (2009). Research Design: Qualitative, Quantitative, and Mixed Methods Approaches (3rd ed.). Thousand Oaks, CA: Sage Publications.

Cudny, W., \& Rouba, R. (2012). Lodz Fashion Week as an example of a business event. Acta Geographica Universitatis Comenianae, 56(1), 45-58.

Demirović, D., \& Pivac, T. (2013). Belgrade (Serbia) as an alternative site or city of fashion tourism. European Researcher, 65(12-2), 2882-2891.

Erkan, I., \& Elwalda, A. (2018). Your comments are important to me! The impacts of online customer reviews in shopping websites. International Journal of Internet Marketing and Advertising, 12(1), 1-18. https://dx.doi.org/10.1504/IJIMA.2018.089200

Geissinger, A., \& Laurell, C. (2020). Multibrand Events and Social Media Engagement: Concentration or Spillover?. Event Management, 24(2-3), 253-262. $\underline{\text { https://doi.org/10.3727/152599519X15506259856011 }}$

Getz, D. (2005). Event management and event tourism (2nd ed.). New York, NY: Cognizant Communication.

Getz, D. (2008). Event tourism: Definition, evolution, and research. Tourism Management, 29(3), 403-428. https://doi.org/10.1016/j.tourman.2007.07.017 
Glaser, B., \& Strauss, A. (1967). The discovery of grounded theory: Strategies for qualitative research. London, UK: Weidenfeld and Nicholson.

- Grohs, R. (2016). Drivers of brand image improvement in sports-event sponsorship. International Journal of Advertising, 35(3), 391-420. https://doi.org/10.1080/02650487.2015.1083070

Gwinner, K. (1997). A model of image creation and image transfer in event sponsorship. International Marketing Review, 14(3), 145-158. https://www.emerald.com/insight/content/doi/10.1108/02651339710170221/full/html

Hennig-Thurau, T., Gwinner, K. P., Walsh, G., \& Gremler, D. D. (2004). Electronic word-ofmouth via consumer-opinion platforms: what motivates consumers to articulate themselves on the internet? Journal of Interactive Marketing, 18(1), 38-52.

\section{https://doi.org/10.1002/dir.10073}

Hsu, Y., \& Tran, T.H. C. (2013). Social relationship factors influence on e-WOM behaviors in social networking sites: empirical study: Taiwan and Vietnam, International Journal of Business, Humanities and Technology, 3(3), 22-31. https://www.ijbhtnet.com/journals/Vol_3_No_3_March_2013/3.pdf

IFEMA (2020). MBFWMadrid. https://www.ifema.es/mbfw-madrid

Jägel, T., Keeling, K., Reppel, A., \& Gruber, T. (2012). Individual values and motivational complexities in ethical clothing consumption:A means-end approach. Journal of 
Marketing Management, 28(3/4), 373-396.

https://doi.org/10.1080/0267257X.2012.659280

Jago, L. K., \& Shaw, R. N. (1998). Special events: A conceptual and definitional framework. Festival management and event tourism, 5(1-2), 21-32. https://doi.org/10.3727/106527098792186775

Javalgi, R. G., Traylor, M. B., Gross, A. C., \& Lampman, E. (1994). Awareness of sponsorship and corporate image: An empirical investigation. Journal of Advertising, 23(4), 47-58. https://doi.org/10.1080/00913367.1943.10673458

Ko, Y. J., Chang, Y., Park, C., \& Herbst, F. (2017). Determinants of consumer attitude toward corporate sponsors: A comparison between a profit and nonprofit sport event sponsorship. Journal of Consumer Behaviour, 16(2), 176-186.

https://doi.org/10.1002/cb.1622

Kvale, S. (1983). The Qualitative Research Interview: A Phenomenological and a Hermeneutical Mode of Understanding. Journal of Phenomenological Psychology, 14(1-2), 171-196. https://doi.org/10.1163/156916283X00090

Lee, M. S., Sandler, D. M., \& Shani, D. (1997). Attitudinal constructs towards sponsorship. International Marketing Review, 14(3), 159-169.

https://doi.org/10.1108/02651339710170230 
Lundblad, L., \& Davies, I.A. (2016). The values and motivations behind sustainable fashion consumption. Journal of Consumer Behaviour, 15(2), 149-162. https://doi.org/10.1002/cb.1559

Mair, J., \& Whitford, M. (2013). An exploration of events research: event topics, themes and emerging trends. International Journal of Event and Festival Management, 4(1), 6-30. https://doi.org/10.1108/17582951311307485

McKinsey (2020). The State of Fashion.

https://www.mckinsey.com/ /media/McKinsey/Industries/Retail/Our\%20Insights/The $\% 20$ state $\% 20$ of $\% 20$ fashion $\% 202020 \% 20$ Navigating\%20uncertainty/The-State-ofFashion-2020-final.pdf

Meyers-Levy, J., \& Tybout, A. M. (1989). Schema congruity as a basis for product evaluation. Journal of Consumer Research, 16(1), 39-54. https://doi.org/10.1086/209192

Mohr, I. (2013). The impact of social media on the fashion industry. Journal of Applied Business and Economics, 15(2), 17-22. http://www.nabusinesspress.com/JABE/MohrI_Web15_2_.pdf

Ragin, C. C. (2000). Fuzzy-set social science. Chicago: The University of Chicago Press.

Ragin, C. C. (2008). Redesigning social inquiry: Fuzzy sets and beyond. Chicago: University of Chicago Press. 
Ragin, C. \& Sonnett, J. (2005). Between complexity and parsimony: Limited diversity, counterfactual cases, and comparative analysis. In S. Kropp \& M. Minkenberg (Eds.), Vergleichen in der Politikwissenschaft, VS Verlag für Sozialwissenschaften. https://link.springer.com/chapter/10.1007/978-3-322-80441-9_9

Rocamora, A. (2017). Mediatization and digital media in the field of fashion. Fashion Theory, 21(5), 505-522. https://doi.org/10.1080/1362704X.2016.1173349

Sachuk, M. I., \& Corrêa, T. C. (2007). Ferramentas de marketing utilizadas em organização de eventos: o caso do Paraná Fashion. Gestão \& Regionalidade, 23(67), 39-51. https://seer.uscs.edu.br/index.php/revista_gestao/article/view/73

Shand, P. (2014). When the event is insufficient - An opposite story of New Zealand Fashion Week. In K. M. Williams, J. Laing, \& W. Frost (Eds.), Fashion, Design and Events (87-101). New York, NY: Routledge.

Schneider, M. R., Schulze-Bentrop, C., \& Paunescu, M. (2010). Mapping the institutional capital of high-tech firms: A fuzzy-set analysis of capitalist variety and export performance. Journal of International Business Studies, 41(2), 246-266. https://link.springer.com/article/10.1057/jibs.2009.36

So, K. K. F., King, C., Sparks, B. A., \& Wang, Y. (2016). The role of customer engagement in building consumer loyalty to tourism brands. Journal of Travel Research, 55(1), 64-78. https://doi.org/10.1177/0047287514541008 
Solomon, Michael (1996), Consumer Behavior, New Jersey: Prentice Hall, Inc.

Statista (2020). Sustainable fashion consumption in Italy. https://www-statista-

\section{com.uow.idm.oclc.org/study/71217/sustainable-fashion-consumption-in-italy/}

Tsiotsou, R., \& Alexandris, K. (2009). Delineating the outcomes of sponsorship: sponsor image, word of mouth, and purchase intentions. International Journal of Retail \& Distribution Management, 37(4), 358-369.

https://doi.org/10.1108/09590550910948583

Verhoef, P., Reinartz ,W., \& Krafft, M. (2010). Customer engagement as a new perspective in customer management. Journal of Service Research, 13(3), 247-252. https://doi.org/10.1177/1094670510375461

Vermeer, S. A., Araujo, T., Bernritter, S. F., \& van Noort, G. (2019). Seeing the wood for the trees: How machine learning can help firms in identifying relevant electronic wordof-mouth in social media. International Journal of Research in Marketing, 36(3), 492508. https://doi.org/10.1016/j.ijresmar.2019.01.010

Wang, Y., and D. R. Fesenmaier. (2004). Towards understanding members' general participation in and active contribution to an online travel community. Tourism Management, 25(6), 709-22. https://doi.org/10.1016/j.tourman.2003.09.011 
Webster, K. (2014). Creating wow in the fashion industry - Reflecting on the experience of Melbourne Fashion Festival. In K. M. Williams, J. Laing, \& W. Frost (Eds.), Fashion, Design marketing and Events (118-130). New York, NY: Routledge.

Westbrook, R. A. (1987). Product/consumption-based affective responses and postpurchase processes. Journal of Marketing Research, 24(3), 258-270. $\underline{\text { https://doi.org/10.2307/3151636 }}$

Woodside, A. G. (2013). Moving beyond multiple regression analysis to algorithms: Calling for adoption of a paradigm shift from symmetric to asymmetric thinking in data analysis and crafting theory. Journal of Business Research, 66(4), 463-472. https://doi.org/10.1016/j.jbusres.2012.12.021

Woodside, A. G. (2014). Embrace perform model: Complexity theory, contrarian case analysis, and multiple realities. Journal of Business Research, 67(12), 2495-2503. https://doi.org/10.1016/j.jbusres.2012.12.021

Wu, P. L., Yeh, S. S., \& Woodside, A. G. (2014). Applying complexity theory to deepen service dominant logic: Configural analysis of customer experience-and-outcome assessments of professional services for personal transformations. Journal of Business Research, 67(8), 1647-1670. https://doi.org/10.1016/j.jbusres.2014.03.012

Yin, R. K. (2015). Qualitative Research: From Start to Finish. New York, NY: Guilford Publications. 
Table 1: Spearman's correlation coefficients

\begin{tabular}{|c|c|c|c|}
\hline \multirow[b]{2}{*}{ Variable } & \multicolumn{3}{|c|}{ Correlations matrix (Spearman's rho) } \\
\hline & 1 & 2 & 3 \\
\hline 1. e-WOM (Y) & 1.000 & & \\
\hline 2. Enjoy (X1) & 0.301 & 1.000 & \\
\hline 3. Fashion (X2) & $0.566 * *$ & 0.341 & 1.000 \\
\hline 4. Sustainability (X3) & $0.442 *$ & 0.004 & 0.289 \\
\hline \multicolumn{4}{|c|}{ **. Correlation is significant at the 0.01 level (2-tailed) } \\
\hline \multicolumn{4}{|c|}{$*$. Correlation is significant at the 0.05 level (2-tailed) } \\
\hline \multicolumn{4}{|c|}{ Source: Own compilation } \\
\hline
\end{tabular}


Table 2: Analysis of necessary conditions

\begin{tabular}{rcr}
\hline Outcome variable: & e-WOM & \\
Conditions tested & Consistency & Coverage \\
cs_X1_Enjoy & 0.571070 & 0.848447 \\
$\sim$ cs_X1_Enjoy & 0.726589 & 0.622939 \\
cs_X2_Fashion & $\mathbf{0 . 8 0 1 8 4 0}$ & 0.793218 \\
$\sim$ cs_X2_Fashion & 0.512542 & 0.618567 \\
cs_X3_Sustainability & 0.635452 & 0.922330 \\
$\sim$ cs_X3_Sustainability & 0.764214 & 0.664244 \\
Note: cs_denotes presence of the condition and $\sim$ cs_denotes absence of the \\
condition \\
Source: Own compilation
\end{tabular}


Table 3: Sufficient configurations for e-WOM

\begin{tabular}{cccc}
\hline Causal configuration & Raw coverage & Unique coverage & Consistency \\
\hline$\sim$ cs_X1_Enjoy* cs_X2_Fashion & $\mathbf{0 . 6 1 9 5 6 5}$ & 0.209030 & 0.827933 \\
cs_X2_Fashion * cs_X3_Sustainability & 0.528428 & 0.117893 & 0.908046
\end{tabular}

Solution coverage: $\mathbf{0 . 7 3 7 4 5 8}$

Solution consistency: $\mathbf{0 . 8 2 5 8 4 3}$

Note: cs_denotes presence of the condition and $\sim c s_{-}$denotes absence of the condition 